This PDF is a selection from an out-of-print volume from the National Bureau of Economic Research

Volume Title: Twenty-third Annual Report of the National Bureau of Economic Research

Volume Author/Editor: Wesley C. Mitchell

Volume Publisher: NBER

Volume URL: http://www.nber.org/books/unkn43-4

Publication Date: 1943

Chapter Title: Production and Productivity

Chapter Author: Wesley C. Mitchell

Chapter URL: http://www.nber.org/chapters/c5403

Chapter pages in book: (p. $17-18)$ 


\section{Production and Productivity}

MANUFACTURING INDUSTRIES

Employment in Manufacturing, 1899-1939: An Analysis of its Relation to Production (in press) complements the volume published in 1940, The Output of Manufacturing Industries, I899-1937. It completes the initial National Bureau study of production and productivity financed by the Maurice and Laura Falk Foundation of Pittsburgh. A byproduct of the study appeared as Occasional Paper 7, Productivity of Labor in Peace and War.

SoLomon Fabricant

NONMANUPACTURING INDUSTRIES

American Agriculture, 1899-1939: A Study of Output, Employment and Productivity by Harold Barger and Hans $\mathrm{H}$. Landsberg was published in January. A manuscript on the mining industries is being reviewed by a staff committee. Besides containing indexes of output, employment, and productivity, it reviews technological changes in the various mineral industries and discusses the relation between technology and resource utilization and depletion.

The transportation industries have proved a more extensive and diversified field of investigation than was first expected. Special attention is being given the competitive relations among transportation industries and to the theoretical problems involved in measuring output in this field. A real effort is being made to measure the output of the transportation industries as a whole. I hope that the completed report, covering the period since 1899 , will be in the hands of the staff committee before the end of March. Some of our preliminary figures on waterborne transportation were released to the Department of Commerce and the War Shipping Administration.

No further work was done during the year upon our study of public utilities. Work on the basic material on electric light and power, manufactured gas, and the communication industries, some of which goes back to 1890 , is completed. A report will be written as soon as other commitments allow.

Only preliminary work has so far been done in the field of construction. It seemed better to wait for the full results of the 1939 Census. The statistical work will be undertaken and a report drafted as soon as practicable. 
A question of great importance in relation to postwar readjustment is the probable future status of the various branches of the economy as a source of livelihood. If we assume that many of the trends observable in the past will reassert themselves when the war is over, the analysis of these trends can contribute to such readjustment and can indicate what developments may be hoped for, what are problematical, and what cannot be relied upon. The reports on manufacturing and agriculture have already borne fruit of this kind. Other reports dealing with mining, transportation, and public utilities, and above all the study of the service industries, will greatly amplify our information.

Harold Barger

SERVICE INDUSTRIES

A grant received late in 1942 from the Maurice and Laura Falk Foundation for a study of the Service Industries and the National Economy makes it possible to round out our investigations of production and productivity. This study will supplement the investigations by Messrs. Fabricant and Barger of manufacturing, agriculture, mining, transportation, public utilities, and construction, and provide information that will enable us to learn something about the industries that produce services instead of commodities; e.g., retail and wholesale trade, domestic service, amusements, the medical and other professions, engineering, and government, most of which cater both to consumers and to business concerns. Growing steadily, these industries employed some 35 per cent of all gainfully occupied persons before this war. Knowledge of the course of their development is essential to an understanding of the history of total employment in this country, and to anticipating the part the service industries may be expected to take in meeting postwar problems of employment and unemployment. This study of the changing employment, efficiency, and product of the services will, when combined with our inquiries into industrial output, efficiency, and employment, complete a survey of variations of output and productivity in virtually the entire American economy.

\section{Labor}

The plan is to publish this year two short monographs on selected phases of the relation of labor to the war. The first will deal with 